\title{
CONSIDERATIONS REGARDING THE FIRST PRELIMINARY RULING OF THE HIGH COURT OF CASSATION AND JUSTICE
}

\author{
Aurelia Cotutiu \\ A. Cotuţiu, G.V.Sabău \\ Faculty of Law \\ " Vasile Goldiş" Western University, Arad, Romania \\ * Correspondesnce: Aurelia Cotuţiu, "Vasile Goldiş" Western University, B.dl. Revoluţiei nr. \\ 94, Arad, Romania \\ E-mail: aureliacotutiu@yahoo.com

\section{Georgeta Valeria Sabău} \\ Faculty of Law \\ " Vasile Goldiş" Western University, Arad, Romania \\ * Correspondesnce: Georgeta Valeria Sabău, "Vasile Goldiş" Western University, B.dl. \\ Revoluţiei nr. 94, Arad, Romania \\ E-mail: georgetasabau@yahoo.com
}

\begin{abstract}
Our intention is to observe the way activity was organized for the solution of legal matters by means of the preliminary ruling of the High Court of Cassation and Justice, to analyze the first notification and the first decision of the special panel in civil matters, and subsequently lay down proposals for the accountability of those involved in the new procedural "mechanism", already in use.
\end{abstract}

Key words: preliminary ruling, first decision, civil matters, High Court of Cassation and Justice, indicator for the evaluation of judges' professional performance

\section{Introduction}

The homepage of the High Court of Cassation and Justice (HCCJ) introduced the Panel for the solution of legal matters and its interface contains information about jurisdiction, a guide and forms, in civil and criminal matters, in a synthetic and enlightening wording. As a work tool, an array of notifications by years was drawn up, with information regarding the case files and hearing sessions and the full text of the notification ruling as well as of the decision given by the Panel for the solution of legal matters, which, for reasons of brevity, we will call the Panel for preliminary ruling.

The first notification regards the matter of immovable forced execution, it dates from the $5^{\text {th }}$ of June 2013, belongs to a panel of the Court of Appeal of Braşov and tends to solve the manner of interpreting and enforcing the provisions of Art. 650 and 651 in relation to Art. 818 and 819 of the New Civil Procedure Code (NCPC), respectively to determine the executing court having the territorial jurisdiction to judge the request for approval of the immovable forced execution when the immovable property pursued is located within the jurisdiction of a law court and the office of the legal executor notified in order to conduct the forced execution is within the jurisdiction of another law court, but both courts are within the jurisdiction of the same court of appeal. 


\section{CONSIDERATIONS REGARDING THE FIRST PRELIMINARY RULING OF THE HIGH \\ COURT OF CASSATION AND JUSTICE}

The first hearing date was set on the $18^{\text {th }}$ of November 2013 when Decision no. $1 / 2013^{1}$ on the solution of matters of law that are the object of Case File no. 1/1/2013/HP was pronounced. Surprisingly enough, the solution found by the 13 judges, five from each civil division, as well as the HCCJ Vice-President, the President of the First Civil Division and the Delegate President of the Second Civil Division, was to reject as inadmissible the notification made by the Court of Appeal of Braşov.

The ruling of the Court of Appeal of Braşov for the notification of the HCCJ, in the account of the lawsuit, presents the request of a legal executor's office headquartered in Braşov, for the approval of forced execution of an immovable property located in the municipality of Sf. Gheorghe, registered at the Law Court of Sf. Gheorghe. The court declined jurisdiction to resolve the request for approval of the immovable forced execution in favour of the Law Court of Braşov, within the jurisdiction of which the office of the requesting legal executor is located. The latter, given that the immovable property which is the object of the forced execution is located in the municipality of Sf. Gheorghe, declined jurisdiction to resolve the case in favour of the court that was first notified and noting the negative conflict of jurisdiction arising between the two courts, sent the case file to the Court of Appeal of Braşov, for it to decide on the competent court.

The viewpoint of the panel of judges ${ }^{2}$, after presenting the rules of law contained in the NCPC (New Civil Procedure Code), applicable with regard to the executing court and the legal executor competent, namely Art. 650, 651 and Art. 818, 819 regarding the request for forced execution and its registering ${ }^{3}$, the Braşov Court of Appeal and the national relevant,

\footnotetext{
${ }^{1}$ Published in the Official Journal, Part I, no. 43 of 20st January 2014

${ }^{2}$ The panel of judges acts on behalf of the court it belongs to, see Ion Deleanu, Tratat de procedură civilă (Treatise of Civil Procedure), Volume I, Editura Universul Juridic (Publishing House), Bucharest, 2013, p. 594.

${ }^{3}$ Art. 650 The executing court

(1) The executing court is the law court in whose jurisdiction the office of the legal executor who conducts the execution is located, unless the law provides otherwise.

(2) The executing court resolves the requests for approval of the forced execution, the appeals against the execution, as well as any other incidents occurring during the forced execution, except those reserved by law to
} the competence of other courts or bodies.

(3) The judgments pronounced by the executing court are binding and may only be challenged through appeal, within 10 days of communication, unless the law provides otherwise.

Art. 651 The legal executor

(1) Unless the law provides otherwise, judgments and other writs of execution are executed by the legal executor within the jurisdiction of the court of appeal, as follows:

a) in the case of the legal seizure of immovable property, legal seizure of fruits attached to roots and of direct forced execution of immovable property, the legal executor within the jurisdiction of the court of appeal where the immovable property is located;

b) in the case of the legal seizure of movable property and direct forced execution of movable property, the legal executor within the jurisdiction of the court of appeal where the residence or, where appropriate, the headquarters of the debtor is located;

c) in the case of forced execution of obligations to do and obligations not to do, the legal executor within the jurisdiction of the court of appeal where the execution is to be carried out.

(2) If the movable or immovable property to be seized is within the jurisdiction of several courts of appeal, any of the legal executors attached to one of these courts has the competence to carry out the execution, including with regard to the seizable property that is within the jurisdiction of the other courts of appeal.

(3) If the movable property subject to legal seizure or direct forced execution was moved during the execution procedure, the territorial competence belongs to the legal executor who began the execution procedure.

(4) Failure to comply with the provisions of this article triggers unconditional nullity of the procedural acts executed.

Art. 818 The forced execution request

(1) The forced execution request, accompanied by the writ of execution and the proof of payment of the stamp duties, will be directed at the legal executor in the jurisdiction of the court of appeal in whose territorial range is the immovable property belonging to the pursued debtor or to another person, if a mortgaged immovable property is pursued.

(2) However, if an immovable property spanning over multiple jurisdictions, the request may be addressed to any legal executors having the competence to carry out the forced execution, at the creditor's choice. 


\section{A. Cotutiu, G. V. Sabău}

but non-unitary, jurisprudence, was that "the executing court competent to resolve the request for approval of immovable forced execution is the court (trial court) in whose jurisdiction is located the immovable property subject to legal seizure, even if the office of the legal executor notified to carry out the execution is within range of another court (trial court)".

The first reasoning in determining the executing court is based on the criterion introduced by Art. 650 the location of the office of the legal executor performing the execution and by Art. 651 which establishes a "functional competence of any executor within the jurisdiction of the court of appeal", thus resulting the three hypotheses of Art. 651 para. 1, depending on the nature of the forced execution.

Continuing with the second reasoning, the panel of judges ${ }^{4}$ held that, in the matter of legal seizure of immovable property, the provisions of Art. 651 para. 1 letter a) are to be correlated with those of Art. 818 and 819, thus resulting that the executing court is the one in whose jurisdiction the pursued immovable property is located and that the special rule establishes "an absolute territorial jurisdiction in the case of legal seizure of immovable property".

By applying the syllogism to the specific case, for the immovable property subject to forced execution located in Sf. Gheorghe municipality, it was concluded that any legal executor within the jurisdiction of the Court of Appeal of Braşov may conduct the forced execution, therefore the notified legal executor operating in Braşov as well, and the executing court for immovable property is the one in whose area the immovable property is located, the trial court of Sf. Gheorghe.

Here is the theorized conclusion of the Court of Appeal of Braşov ${ }^{5}$ which is worth rendering here, for its clarity and brevity: "The fact that the provisions of Art. 818 para. 2 NCPC allow the creditor to choose the legal executor operating within range of the law courts that are in the jurisdiction of the entire court of appeal on whose territory the immovable property is located does not mean that the legal executor may, in turn, choose the executing court, the provisions of Art. 819 being imperative and absolute, for reasons related to the necessity to perform the execution acts at the place of the immovable property for a better turning to account of the latter".

The admissibility grounds retained by the holder of the notification were judiciously reproduced in the preliminary ruling, from the notification ruling: $>>$ a) on clarifying the manner of interpretation of the provisions of Art. 650 and Art. 651 in relation to Art. 818 and 819 of the Civil Procedure Code adopted through Law no. 134/2010, respectively on determining the executing court having the competence to judge the request for approval of the immovable forced execution, depends the legality of the execution acts given that, according to Art. 651 para. (4) of the Civil Procedure Code adopted through Law no. $134 / 2010$, the sanction for failure to comply with the rules regarding the territorial competence of the legal executor is "unconditional nullity of the procedural acts executed";

b) the stated legal matter is a new one, because by looking through the jurisprudence, it was found that the High Court of Cassation and Justice had not issued a ruling on this matter ${ }^{6}$

(3) The forced execution request will contain the particulars provided for in Art. 663.

Art. 819 Registering of the forced execution request

After the registering of the request, the legal executor will immediately request the executing court in whose jurisdiction the immovable property is located to approve its legal seizure, the provisions of Art. 664 and 665 being enforced accordingly.

${ }^{4}$ This panel of judges enjoys a legally-assigned competence to notify the HCCJ and to present their own point of view, Ion Deleanu, op. cit., p. 595.

${ }^{5}$ Conflicts of jurisdiction are resolved within the law courts through their judicial activity, which is an intrinsic component of justice, Ion Deleanu, op. cit., p. 617.

${ }^{6}$ With regard to the "novelty" of this legal issue, see Viorel Mihai Ciobanu and Marian Nicolae, Noul Cod de procedură civilă comentat şi adnotat (New Civil Procedure Code, commented and annotated), Editura Universul Juridic (Publishing House), Bucharest, 2013, p. 1214. 


\section{CONSIDERATIONS REGARDING THE FIRST PRELIMINARY RULING OF THE HIGH \\ COURT OF CASSATION AND JUSTICE}

c) the legal matter is not subject to a pending appeal on points of law, according to the records of the High Court of Cassation and Justice consulted on the $30^{\text {th }}$ of May 2013. $<<$

The report on the legal matter concluded that "the legal institution's conditions of admissibility regarding the pronouncement of a preliminary ruling for the solution of certain legal matters are not met".

Not surprisingly, the report added a "subsidiary, in case of an opinion about the notification meeting the conditions of admissibility", the opinion of the panel sending the notification was shared, which is "that the interpretation of the provisions of Art. 650 and Art. 651 in relation to Art. 818 and 819 of the Civil Procedure Code adopted through Law no. $134 / 2010$ is in the sense that the executing court having the territorial competence to judge the request for approval of the immovable forced execution when the mortgaged immovable property subject to seizure is located within range of a court (trial court), and the office of the legal executor notified in order to carry out the execution is within range of another court (trial court), but both courts are within range of the same court of appeal, is the court (trial court) in the jurisdiction of which the mortgaged immovable property subject to seizure is located".

The High Court, examining the notification in view of issuing a preliminary ruling, as well as the report, and might we say, without analyzing the legal matter for which a solution is requested, wrongly established, "that the conditions of admissibility of the notification are not met, in view of issuing a preliminary ruling, as required by Art. 519 of the Civil Procedure Code...".

According to the notification, it was for the High Court to determine the court having the territorial competence to judge the request for approval of the immovable forced execution for an immovable property subject to legal seizure located within range of the Trial Court of Sf. Gheorghe, whereas the office of the legal executor notified in order to carry out the execution is within range of another court, the Trial Court of Braşov, both courts being located within range of the same Court of Appeal, that of Braşov.

The Panel for preliminary ruling retained that the conditions imposed by Art. 519 New Civil Procedure Code are partially met, as there is a case pending before the Court of Appeal of Braşov, the object of which is to resolve the regulator of competence as court of last instance, so that "there are no issues of inadmissibility regarding the existence of a dispute and the quality of the notifying court, in which case it is as necessary to analyze the admissibility of the request in relation to the conditions regarding the legal matter whose clarification is sought".

Therefore, "the dependency relation between the legal matter that is the object of the notification and the settlement of the case on the merits" was analyzed, being noted that the lawmaker imposes as a necessity the close connection between the legal matter that is the object of the notification of the High Court and the object of the civil action, "because only by analyzing the actual claim brought before the courts, may they carry out a trial of the case on the merits".

Therefore, what the HCCJ retains is that the content of the ruling issued as part of the regulator of competence for negative conflict of competence, "does not settle the merits of the case, but only a procedural incident, determining which of the two courts should judge..." the request for approval of the immovable forced execution and that "it turns out that the determination of competence is not a matter on which the settlement on the merits might depend".

And it concludes, in principle, that "it is admissible for the problems of procedural law too ${ }^{7}$ to be subject to notification in view of issuing a preliminary ruling, when the solution

\footnotetext{
${ }^{7}$ To contradict this opinion, see Gabriel Boroi and collaborators, Noul Cod de procedură civilă comentariu pe articole (New Civil Procedure Code Commentary by Articles), volume I, Editura Hamangiu (Publishing House), Bucharest, 2013, p.1008.
} 


\section{A. Cotutiu, G. V. Sabău}

in principle given by the supreme court determines the settlement of the case on the merits", but "the legal matter brought into attention does not fall into the category of those on the clarification of which depends the settlement of the merits of the case", therefore the inadmissibility of the notification with regard to issuing a preliminary ruling was substantiated, which prevails and the other elements for the admissibility of the notification were not further scrutinized.

A few terminological considerations, preceding our critical analysis, are needed. Contentious procedure states, in its first article, that the civil lawsuit begins by filing the summons, at the court ${ }^{8}$.

In the regulation of contentious procedure and not only ${ }^{9}$, the lawmaker uses for lawsuit $^{10}$ (trial) the synonyms: case ${ }^{11}$, litigation (dispute) ${ }^{12}$, cause ${ }^{13}$.

But, in order to avoid annoying repetition, they are used together in the very same article - case and lawsuit ${ }^{14}$.

The two Articles 519 and $520^{15}$ dedicated by the New Civil Procedure Code to preliminary ruling prefer the name case, but it is used with multiple meanings.

\section{${ }^{8}$ Art. 192 The right to notify the court}

(1) To protect their rights and legitimate interests, any person may address justice by notifying the competent law court through summons. In cases specifically provided by law, court referral (notification) may be carried out by other persons or bodies, as well.

(2) The lawsuit begins with the filing of the petition at the court, according to the law.

${ }^{9}$ Art. 532-533 of the non-contentious procedure uses the synonym case.

${ }^{10}$ See, in the New Civil Procedure Code, Art. 194, 202, 211, 224, 231, 237, 240, 241, 244, 247, 249, 254, 307, $343,363,389,395,398,414,430,451,458,478,480,498,502$.

${ }^{11}$ See, in the New Civil Procedure Code, Art. 200, 220, 223, 230, 385, 386, 392, 397, 400, 412, 415, 424, 452, 479.

${ }^{12}$ See, in the New Civil Procedure Code, Art. 227, 462.

${ }^{13}$ See, in the New Civil Procedure Code, Art. 399, 525.

${ }^{14}$ We have in view Art. 201, 236, 242, 243, 390, 498, 522, 524 of the New Civil Procedure Code.

${ }^{15}$ Art. 519 The object of the notification

If, during the trial, a panel of judges of the High Court of Cassation and Justice, the Court of Appeal or the County Court, vested with hearing the case in last instance, finding that a legal matter, on the clarification of which depends the settlement of the merits of the case, is new and the High Court of Cassation and Justice has not issued a ruling concerning it, nor is it subject to a pending appeal on points of law, it may request the High Court of Cassation and Justice to give a ruling solving in principle the legal matter about which it was notified.

Art. 520 The trial procedure

(1) The notification of the High Court of Cassation and Justice is done by the panel of judges after adversarial proceedings, if the conditions laid down in Art. 519 were met, through a ruling which is not subject to any means of appeal. If through the ruling notification is ordered, the latter shall include the reasons supporting the admissibility of the notification according to Art. 519, the viewpoint of the panel of judges and of the parties.

(2) Through the ruling provided for in para. (1), the case shall be suspended until the pronouncement of the preliminary ruling for the solution of the legal matter.

(3) After registering the case at the High Court of Cassation and Justice, the notification ruling is published on the website of that court.

(4) Similar cases pending before the courts may be suspended until the resolution of the notification.

(5) The assignment of the notification is done by the President or, in his absence, by one of the vice-presidents of the High Court of Cassation and Justice or by the person appointed by them.

(6) The notification is heard by a panel comprising the president of the appropriate division of the High Court of Cassation and Justice or a judge appointed by him and 12 judges of the respective division. The president of the division or, if unable, the judge appointed by him is the president of the panel and shall take the necessary steps for the random appointment of the judges.

(7) After the formation of the panel according to para. (6), its president shall appoint a judge to draw up a report on the legal matter that was subject to trial. The judge appointed as rapporteur does not become incompatible.

(8) When the legal matter concerns the activity of several divisions of the High Court of Cassation and Justice, the president or, in his absence, one of the vice-presidents of the High Court of Cassation and Justice shall forward the notification to the presidents of the divisions concerned with the resolution of the legal matter. In this case, the panel will be made up of the president or, in his absence, the vice-president of the High Court of Cassation and Justice, who will chair the panel, the presidents of the divisions concerned with the resolution of 


\section{CONSIDERATIONS REGARDING THE FIRST PRELIMINARY RULING OF THE HIGH COURT OF CASSATION AND JUSTICE}

The first meaning: - if, during the trial, a panel of judges of the High Court of Cassation and Justice, the Court of Appeal or the County Court, vested with hearing the case in last instance..., meaning a trial (lawsuit) which is tried in the county court or the Court of Appeal or the HCCJ, without the prospect of another trial, in another court.

In the specific case analyzed, as the HCCJ itself establishes, "it is found that there is a case on trial, and the Court of Appeal of Braşov, vested with solving the regulator of competence, judged (the correct word is "is judging" or "will judge", our underlining) in last instance, according to the law".

- a legal matter, on the clarification of which depends the settlement of the merits of the case..., here, too, the meaning is that of a trial (lawsuit) which is to be resolved in last instance at the county court or court of appeal or the HCCJ, without the prospect of another trial, in another court. We emphasize that the law has in view the same case, from the previous presentation, specifying it's the respective case, not another.

That is, in this specific case, the litigation whose object is the regulator of competence, by which the Braşov Court of Appeal has the obligation to determine whether the executing court is the Trial Court of Sf. Gheorghe or the Trial Court of Braşov and which gave rise to the necessity of clarifying the legal matter, that makes up the object of the notification.

- the case will be suspended until the pronouncement of the preliminary ruling for the solution of the legal matter. Of course, the lawmaker is considering the entire lawsuit (trial) pending in last instance before the county court, the court of appeal or the HCCJ, without the prospect of another trial, in another court, where the legal matter requiring a solution arose, and in the specific case, the regulator of competence which is to be decided by the Court of Appeal of Braşov, after the issue of the ruling by the HCCJ.

The second meaning: - after registering the case at the High Court of Cassation and Justice, here, the term signifies "notification" (referral), in the specific case forming the object of case file no. 1/1/2013/HP of the HCCJ.

The third meaning: - similar cases pending before the courts, the reference is to similar lawsuits (trials), litigations of the same nature, pending before any law courts, having no connection to the procedure unfolding for the pronouncement of the preliminary ruling.

It is necessary to mention a fourth meaning, as well, which is not highlighted by the two articles originating the preliminary ruling and it concerns the initial litigation, the lawsuit understood as a request registered at a court of justice, even a trial court, which by means of appeal or by procedural incident, is before one of the three courts, for settlement, in the last phase of the procedure, either as the proper lawsuit (trial) or another one, derivative from a procedural incident.

In the present case, the proper lawsuit is the legal executor's request for approval of the immovable forced execution, addressed to the Trial Court of Sf. Gheorghe, registered at

the legal matter, as well as 5 judges of the respective divisions randomly appointed by the president of the panel. After the formation of the panel, the president of the panel shall appoint one judge from each division for the drawing up of the report. The rapporteurs are not incompatible.

(9) If at the High Court of Cassation and Justice, there is no division corresponding to the level at which it was found that the legal matter was not uniformly solved in the practice of the courts, the provisions of para. (8) shall apply accordingly.

(10) The report shall be communicated to the parties, which, within 15 days from the communication, may submit, in writing, through a lawyer or, where appropriate, a legal counselor, their views on the legal matter that is subject to judgment.

(11) The provisions of Art. 516 para. (6) - (9) shall apply accordingly.

(12) The notification shall be judged without summoning the parties, within 3 months from the date of vesting, and the solution shall be adopted by at least two thirds of the judges in the panel. Abstentions from voting are not allowed.

(13) The procedure provided in this chapter is exempt from judicial stamp duty and judicial stamp. 


\section{A. Cotutiu, G. V. Sabău}

this court, which desisted from it through civil sentence no. 25/C/06 ${ }^{\text {th }}$ April 2013, the court declining competence in favour of the Trial Court of Braşov.

Through the negative conflict of competence, the proper lawsuit gave rise to a derivative lawsuit, i.e. the one pending before the Court of Appeal of Braşov in order to decide the regulator of competence.

Each case may result in a settlement on the merits, but both as different ones, depending on the different object of the proper lawsuit or the derivative one.

The error of the supreme court has to do entirely with shifting the analysis of the cumulative legal requirements that Art. 519 imposes only for the case pending in last instance before the county court, the court of appeal or the HCCJ..., respectively from the litigation of the Court of Appeal of Braşov having as an object the regulator of competence, to the lawsuit brought before the Trial Court of Sf. Gheorghe, regarding the approval of the immovable forced execution.

This led to a string of erroneous reasonings caused by a lack of elementary logic.

Thus, although it is correctly retained that "the present notification requests the pronouncement of a preliminary ruling for the solution of the manner of interpreting and enforcing the provisions of Art. 650 and Art. 651 in relation to Art. 818 and 819 of the Civil Procedure Code..., respectively the establishment of the executing court having the territorial jurisdiction to judge the request for approval of the immovable forced execution when the immovable property pursued is located within the jurisdiction of a law court (trial court), and the office of the legal executor notified in order to conduct the forced execution is within the jurisdiction of another law court (trial court), but both courts are within the jurisdiction of the same court of appeal", the examination is artificially shifted, outside any of the provisions of Art. 519, to the "object of the civil action, because only by analyzing the actual claim brought before the courts, may they carry out a trial of the case on the merits" (the underlining belongs to the HCCJ decision), hence to the lawsuit for the approval of the forced execution registered at the Trial Court of Sf. Gheorghe.

A correct analysis should have further pursued the case brought in last instance..., i.e. the one that caused the notification of the HCCJ for the solution of the new legal matter aimed at establishing the executing court "on the clarification of which depends the settlement of the merits of the case", which is the one brought before the Braşov Court of Appeal.

In a different order of ideas, if the HCCJ admitted that the approval of the forced execution is the "actual claim brought before the court" and involves "a trial of the case on the merits", it must also accept the fact that the litigation pending before the Court of Appeal of Braşov, derived from the first one as a result of procedural incident, aiming to designate the competent court, has the same legal status as the "actual claim brought before the court" and awaits " $a$ trial of the case on the merits", case to which the High Court of Cassation was notified to contribute by a preliminary ruling.

Our opinion is that the notification of the Court of Appeal of Braşov is admissible and that the decision of the High Court of Cassation and Justice was wrong.

\section{Conclusions}

The use of the institution of preliminary ruling, with three notifications in civil matter having been issued to this date, demonstrates that regulation is necessary, and by implementing the formal tools available on the website of the High Court of Cassation and Justice, it becomes also easy to do.

But the institution, being at the beginning of its existence, must be defended against unprofessional approaches, both of the judges who send notifications and the judges of the High Court of Cassation and Justice who are called to solve them.

We think that a useful tool may be the introduction of an indicator for the evaluation of judges' professional performance in the Regulation concerning the evaluation of 
professional activity of judges and prosecutors ${ }^{16}$, which aims to set a level of professional competence of the judges and to improve their professional performance, to increase the efficiency of the activity of courts and public prosecutors' departments and public confidence in the authority of the judiciary, to maintain and enhance the quality of the judicial system.

Thus, in Art. 5 of the Regulation, section "Quality of Activity", in addition to the two indicators, quality of drafting judgments and conduct during the hearing session, a third one might be introduced, the notification (referral) of the High Court of Cassation and Justice in view of pronouncing a preliminary ruling for the solution of certain legal matters, respectively the participation in the pronouncement of such a ruling, and, as sub-indicators, the identification of new legal matters with major impact on the settlement of cases resolved in a non-unitary manner and the persuasive, concise and clear nature of the notification, respectively the settlement of the notification within its deadline, and a logical and convincing reasoning thereof.

\section{Bibliography:}

1. Deleanu, Tratat de procedură civilă, volume I, Universul Juridic Publishing House, Bucharest, 2013

2. V. M. Ciobanu, M. Nicolae, Noul Cod de procedură civilă comentat şi adnotat, Universul Juridic Publishing House, Bucharest, 2013

3. G. Boroi and collaborators, Noul Cod de procedură civilă comentariu pe articole volume I, Hamangiu Publishing House, Bucharest, 2013

\footnotetext{
${ }^{16}$ Approved by Decision no. 676/2007, published in the Official Journal no. 814/29 ${ }^{\text {th }}$ November 2007, amended.
} 
A. Cotutiu, G. V. Sabău 